\title{
PERSEPSI MASYARAKAT JAWA TERHADAP TEMBANG LINGSIR WENGI SEBAGAI SEBUAH KOMUNIKASI LINTAS BUDAYA SYIAR AGAMA ISLAM (Studi Fenomenologi Kualitatif Tentang Pesan Dibalik Tembang Lingsir Wengi Karya Sunan Kalijaga)
}

\author{
Oleh: Fajar Dwi Putra \\ Fakultas Sastra, Budaya dan Komunikasi Program Studi Ilmu Komunikasi \\ Universitas Ahmad Dahlan Yogyakarta \\ E-mail: jokadesanta@yahoo.com
}

\begin{abstract}
Abstrak
Cara berpikir seseorang akan menentukan apa yang akan dilihatnya. Hasil yang demikian merupakan sebuah pelajaran berharga dari setiap peristiwa yang sedang, sudah atau bahkan akan terjadi. Tembang Lingsir Wengi yang merupakan sebuah ungkapan doa dan dakwah dari sang pembawa ajaran suci agama Islam dianggap sebagai sebuah metode atau ritual khusus untuk memanggil dan mengumpulkan roh halus. Pandangan ini tidak didasari dengan pemahaman dan telaah mendalam, hanya bersifat apriori semata, sehingga yang tidak berdasar pengalaman itu memunculkan persepi atau pandangan yang berbeda jauh dengan aslinya, terlebih ketika tembang ini dijadikan salah satu alunan musik dalam sebuah film horor.

Penelitian ini bertujuan untuk mengubah pandangan masyarakat umum khususnya Jawa agar membuka pola pikir tentang tembang Lingsir Wengi. Bahwa dalam mengambil sebuah keputusan harus didasarkan pada pengalaman mencoba atau melihat, melakukan dan memahami lebih jauh.
\end{abstract}

Kata kunci: Persepsi, Komunikasi Lintas Budaya Masyarakat Jawa.

\section{A. Pendahuluan}

Budaya merupakan sebuah mekanisme parsial yang menjadi sarana untuk berkomunikasi antar bangsa, negara, rakyat ataupun organisasi tertentu. Melalui budaya masyarakat dapat menjelaskan jenis dan bentuk komunikasi yang ada di dalamnya. Komunikasi dalam berbudaya melahirkan satu ensitas tersendiri untuk melihat jendela dunia dalam balutan sosiologi masyarakat. Komunikasi yang terdapat dalam ekologi budaya Jawa memberikan satu pemahaman tersendiri. Banyak pesan yang tersembunyi dibalik budaya dan masyarakat khususnya masyarakat Jawa.

Kebudayaan masyarakat Jawa yang adipeni adalah cerminan perilaku masyarakatnya. Cerminan itu diwujudkan dalam bentuk interaksi sosial. Masyarakat Jawa juga tidak bisa lepas dari persepsi, perilaku, pikiran dan cara pandangnya tentang hal yang berbau supranatural atau klenik. Seperti halnya yang kita ketahui, bahwa suku Jawa adalah suku terbesar di Indonesia, persepsi yang dibentuk merupakan "karya" turun 
temurun yang dilogikakan sebagai bentuk komunikasi antara masyarakat dengan nenek moyang atau yang lazim mereka sebut dengan "leluhur".

Ada banyak cara untuk menyampaikan pesan, salah satunya adalah melalui seni musik. Seni merupakan satu media konferehensif untuk memberikan satu pemahaman tentang pesan yang akan disampaikan. Seperti kita ketahui masyarakat Jawa khususnya Yogyakarta lebih memahami arti pesan melalui sebuah media tertentu seperti wayang, tembang (macapat) dan puisi adalah salah satu media yang dianggap pas untuk menyampaikan pesan, maksud dan tujuan.

Seiring dengan perkembangan zaman, masuknya pengaruh budaya modernisasi dan westernisasi membuat komunikasi semakin berkembang. Teknologi diduga kuat sebagai salah satu alasan munculnya deformasi dalam berbudaya dan berkomunikasi. Ini terbukti dengan semakin tingginya persepsi yang negatif tentang sebuah media penyampaian pesan. Dominasi terbesar dari perubahan bentuk komunikasi adalah dengan hadirnya teknologi internet yang merajai masyarakat, sehingga masyarakat dengan gampang akan terpengaruh oleh media internet. Tidak berhenti sampai disitu, media sosial yang ada saat ini menggiring opini dan persepsi masyarakat untuk memahami apa yang tertulis dalam pesan sosialnya. ini sebuah pekerjaan rumah besar bagi Indonesia untuk mencoba membenahi, meluruskan dan memberikan pemahaman yang baik tentang isu-isu yang tersebar di masyarakat.

Persepsi yang berkembang di masyarakat tentang tembang Lingsir Wengi sudah merujuk kepada hal yang dinilai negatif yaitu sebagai sarana memanggil para hantu atau setan. Stigma demikian tidak bersumber dan tidak bisa langsung dipercaya seutuhnya. Persepsi seperti ini sudah melekat di masyarakat pada umumnya, sehingga memberikan satu pemahaman minor bahwa tembang Lingsir Wengi adalah tembang memanggil roh.

Pandangan masyarakat luas semacam ini perlu diluruskan. Perlu adanya pembenahan secara masif tentang persepsi ini. Meluruskan persepsi memang tidaklah mudah, terlebih persepsi ini sudah mengakar di kalangan masyarakat Jawa. Apa yang menyebabkan pikiran dan pemikiran ini berkembang tidak lepas dari peran masyarakat yang meng-konformitas-kan Lingsir Wengi sebagai sebuah metode pemanggil roh halus.

Masyarakat perlu diberikan satu pemahaman yang riil, kerangka berpikir yang nyata dan kongkrit, sehingga pada akhirnya masyarakat melihat sisi positif dari pesan yang terkandung dibalik tembang Lingsir Wengi. Ini sebuah harapan besar, bahwa cara berpikir yang menghasilkan persepsi merupakan kendaraan yang perlu untuk dikawal sehingga tidak menimbulkan keraguan dan kesalahampahaman di masyarakat.

Pesan adalah sebuah informasi yang disampaikan dengan berbagai media, apapun medianya jika isi pesan mengandung informasi maka sudah layak disebut sebagai sebuah pesan. Pesan yang disampaikan memberikan satu pemikiran tersendiri. Masyarakat Jawa khususnya, karena budaya masyarakatnya masih kental dengan ke-tradisionalan maka pesan yang akan disampaikan juga melalui media yang bersifat tradisional atau konvensional.

Definisi pertama tentang komunikasi, penulis mengutip dari pendapat Cerrey yang mengatakan bahwa komunikasi merupakan satu proses "ritual" yang mengemukakan informasi melalui dua model. (1) model transmisi, yaitu model yang secara tidak langsung mengutamakan perluasan pesan dalam ruang, tapi diarahkan untuk 
Diterbitkan oleh Program Studi IImu Komunikasi

Universitas Ahmad Dahlan Yogyakarta

mengelola masyarakat dalam satuan waktu, sebuah model yang tidak memerlukan tindakan untuk mengambil bagian dari informasi tetapi representatif dari sebuah keyakinan. (2) sebagai pola dasar suatu "ritual" untuk menarik orang agar turut serta dalam kebersamaan.

Kegiatan komunikasi memang merupakan kegiatan mengirim atau menerima pesan, namun pada ghalibnya pesan sama sekali tidak berpindah, yang berpindah adalah makna pesan tersebut. Para ahli komunikasi mengatakan bahwa komunikasi adalah kegiatan "pertukaran makna", makna itu ada di dalam setiap orang yang mengirimkan pesan. Jadi, makna bukan sekedar pesan verbal non verbal, tetapi makna adalah pesan yang dimaksudkan oleh si pengirim dan diharapkan akan dimengerti juga oleh si penerima. Persoalannya adalah bagaimana setiap orang mampu membuat kata-kata menjadi bermakna?

Komunikasi, baik dari arti simbolik, proses maupun pertukaran makna selalu ada dalam beberapa bentuk yaitu komunikasi antarpdibadi, kelompok kecil dan kelompok besar, organisasi publik dan massa. Dan pelbagai itu bergerak mulai dari komunikasi dua orang (dyad) hingga tiga orang (triad).

Pada intinya, setiap pesan yang disampaikan bergantung dari persepsi si penerima pesan. Ini yang menjadi telaah peneliti untuk terus menggali data tentang fonomenologi pesan di balik lagu "Lingsir Wengi". Pesan yang terkandung didalamnya sudah menjadi "konsumsi" publik dan masyarakat cenderung salah mengartikannya. Ini membuktikan bahwa persepsi mempengaruhi cara pandang seseorang dalam menerima sebuah pesan informasi.

\section{B. Kerangka Teori}

\section{Pengertian Persepsi}

Persepsi: merupakan suatu proses yang didahului oleh penginderaan, yaitu suatu stimulus yang diterima oleh individu melalui alat reseptor yaitu indera. Alat indera merupakan penghubung antara individu dengan dunia luarnya. Persepsi merupakan stimulus yang diindera oleh individu, diorganisasikan kemudian diinterpretasikan sehingga individu menyadari dan mengerti tentang apa yang diindera.

Faktor-faktor yang mempengaruhi persepsi pada dasarnya dibagi menjadi dua, yaitu: Faktor Internal dan Faktor Eksternal. (1). Faktor Internal yang mempengaruhi persepsi, yaitu faktor-faktor yang terdapat dalam diri individu, yang mencakup beberapa hal antara lain: Fisiologis. Informasi masuk melalui alat indera, selanjutnya informasi yang diperoleh ini akan mempengaruhi dan melengkapi usaha untuk memberikan arti terhadap lingkungan sekitarnya. Kapasitas indera untuk mengolah persepsi pada tiap orang berbeda-beda sehingga interpretasi terhadap lingkungan juga dapat berbeda.

Perhatian. Individu memerlukan sejumlah energi yang dikeluarkan untuk memperhatikan atau memfokuskan pada bentuk fisik dan fasilitas mental yang ada pada suatu obyek. Energi tiap orang berbeda-beda sehingga perhatian seseorang terhadap obyek juga berbeda dan hal ini akan mempengaruhi persepsi terhadap suatu obyek. 
Minat. Persepsi terhadap suatu obyek bervariasi tergantung pada seberapa banyak energi atau perceptual vigilance yang digerakkan untuk mempersepsi. Perceptual vigilance merupakan kecenderungan seseorang untuk memperhatikan tipe tertentu dari stimulus atau dapat dikatakan sebagai minat.

Kebutuhan yang searah. Faktor ini dapat dilihat dari bagaimana kuatnya seseorang individu mencari obyek-obyek atau pesan yang dapat memberikan jawaban sesuai dengan dirinya.

Pengalaman dan ingatan. Pengalaman dapat dikatakan tergantung pada ingatan dalam arti sejauh mana seseorang dapat mengingat kejadian-kejadian lampau untuk mengetahui suatu rangsang dalam pengertian luas.

Suasana hati. Keadaan emosi mempengaruhi perilaku seseorang, mood ini menunjukkan bagaimana perasaan seseorang pada waktu yang dapat mempengaruhi bagaimana seseorang dalam menerima, bereaksi dan mengingat. (2). Faktor Eksternal yang mempengaruhi persepsi, merupakan karakteristik dari lingkungan dan obyek-obyek yang terlibat didalamnya. Elemen-elemen tersebut dapat mengubah sudut pandang seseorang terhadap dunia sekitarnya dan mempengaruhi bagaimana seseoarang merasakannya atau menerimanya. Sementara itu faktor-faktor eksternal yang mempengaruhi persepsi adalah: Ukuran dan penempatan dari obyek atau stimulus. Faktor ini menyatakan bahwa semakin besarnya hubungan suatu obyek, maka semakin mudah untuk dipahami. Bentuk ini akan mempengaruhi persepsi individu dan dengan melihat bentuk ukuran suatu obyek individu akan mudah untuk perhatian pada gilirannya membentuk persepsi.

Warna dari obyek-obyek. Obyek-obyek yang mempunyai cahaya lebih banyak, akan lebih mudah dipahami (to be perceived) dibandingkan dengan yang sedikit.

Keunikan dan kekontrasan stimulus. Stimulus luar yang penampilannya dengan latarbelakang dan sekelilingnya yang sama sekali di luar sangkaan individu yang lain akan banyak menarik perhatian.

Intensitas dan kekuatan dari stimulus. Stimulus dari luar akan memberi makna lebih bila lebih sering diperhatikan dibandingkan dengan yang hanya sekali dilihat. Kekuatan dari stimulus merupakan daya dari suatu obyek yang bisa mempengaruhi persepsi.

Motion atau gerakan. Individu akan banyak memberikan perhatian terhadap obyek yang memberikan gerakan dalam jangkauan pandangan dibandingkan obyek yang diam.

\section{Proses Persepsi}

Menurut Anton Raditya (2003:145), proses terbentuknya persepsi didasari pada beberapa tahapan, yaitu:

a. Stimulus atau rangsangan

Terjadinya persepsi diawali ketika seseorang dihadapkan pada suatu stimulus/rangsangan yang hadir dari lingkungan.

b. Registrasi

Dalam proses registrasi, suatu gejolak yang nampak adalah mekanisme fisik yang berupa pengindraan dan syarat seseorang berpengaruh melalui alat indera 
Diterbitkan oleh Program Studi IImu Komunikasi

Universitas Ahmad Dahlan Yogyakarta

yang dimilikinya. Seseorang dapat mendengarkan atau melihat informasi yang terkirim kepadanya, kemudian mendaftar semua informasi yang terkirim kepadanya.

c. Interpretasi

Intrepretasi merupakan suatu aspek kognitif atau persepsi yang sangat penting yaitu proses memberikan arti kepada stimulus yang diterimanya. Proses intrepretasi tersebut bergantung pada cara pendalaman, motivasi dan kepribadian seseorang.

d. Karakter Masyarakat Jawa

Suku Jawa merupakan salah satu suku terbesar yang berdiam di negara Indonesia. Sebagai buktinya, kemana pun kita melangkahkan kaki ke bagian pelosok penjuru negeri ini, kita pasti akan menemukan suku-sukuJawa yang mendiami kawasan tersebut meskipun terkadang jumlahnya minorotas.Suku Jawa hampir menyebar merata di seluruh pelosok tanah air. Tak hanya karena keragaman budayaJawa yang cukup menjadi icon bangsaIndonesia pada tingkat budaya nasional, namun juga keramahtamahankhas suku ini juga menjadi kesan yang cukup mendalam di hati para wisatawan asing yang berkunjung ke Indonesia. Dari pengertian diatas, merujuk pemahaman tentang karakter masyarakat Jawa, menurutRahyono (2015) karakter masyarakat atau suku Jawa diklasifikasikan kedalam tiga item yaitu:

Suku Jawa diidentikkan dengan berbagai sikap sopan, segan, menyembunyikan perasaan alias tidak suka langsung-langsung, menjaga etika ber-bicara baik secara konten isi dan bahasa perkataan maupun objek yang diajak berbicara. Bahasa Jawa adalah bahasa ber-strata, memiliki berbagai tingkatan yang disesuaikan dengan objek yang diajak bicara. Suku Jawa umumnya mereka lebih suka menyembunyikan perasaan. Menampik keinginan hati demi sebuah etika dan sopan santun sikap yang dijaga. Misalnya saat bertamu dan disuguhi hidangan. Karakter khas seorang yang bersuku Jawa adalah me-nunggu dipersilahkan untuk mencicipi, bahkan terkadang sikap sungkan mampu melawan kehendak atau keinginan hati.

Soal etika, suku Jawa memang sangat menjunjung tinggi persoalan yang satu ini. Baik secara sikap maupunberbicara. Untuk berbicara, seorang yang lebih muda hendaknya menggunakanbahasa Jawa halus yangterkesan lebih sopan.Berbeda dengan bahasa yang digunakan untuk rekan sebaya maupun yang usianya di bawah.Demikian juga dengan sikap, orang yang lebih muda hendaknya betul-betul mampu menjaga sikap etika yangbaik terhadap orang yang usianya lebih tua dari dirinya.

Suku Jawa itu sendiri terdiri dari berbagai macam jenis tergantung pada lokasi daerah mereka berdiam. Biasanya secara lebih khusus lagi, setiap suku Jawa tersebut memiliki ragam kebudayaan yang lebih khas lagi, baik soal bahasa, adat kebiasaan, makanan khas dan sebagainya. 


\section{Sejarah Tembang Lingsir Wengi}

Lingsir wengi merupakan salah satu lagu gending jawa yang menggunakan pakem macapat, pakem macapat terdiri dari 11 pakem salah satunya pakem durma yang dipakai dalam lagu lingsir wengi.

Lagu ini sempat menjadi lagu populer ketika keberadaannya digunakan sebagai backsound sebuah film Indonesia yaitu serial Kuntilanak, film tersebut menyajikan film horor dimana lagu lingsir wengi dilarang dinyanyikan pada waktu tertentu, karena akan mengundang mahluk gaib yaitu kuntilanak. Dari film ini timbul makna negatif dari masyarakat tentang lagu ini, padahal sejarah dari lagu ini begitu baik dan patut untuk kita ketahui. Lagu lingsir wengi merupakan lagu yang diciptakan oleh Sunan Kalijaga, lahir sekitar tahun 1450 SM dengan nama kecil Raden Said. Sunan Kalijaga salah satu wali yang menyebarkan ajaran Islam dengan media budaya jawa, seperti wayang kulit, seni ukir, gamelan, dan yang lain.

Durmo lingsir wengi merupakan arti lagu penolak mahluk halus, namun masyarakat salah mengartikan menjadi pengundang mahkluk halus. Lagu lingsir wengi diciptakan sebagai penolak bala godaan mahluk halus. Persepsi yang demikian sudah mewabah di masyarakat, khususnya masyarakat Jawa. Film Kuntilanak menjadikan persepsi tentang lagu ini semakin keluar dari jalur atau anomali, banyak yang belum mamahami makna asli dari syair lagu Lingsir wengi. Masyarakat luas beranggapan bahwa lagu ini adalah pemanggil roh halus karena lagu ini muncul di salah atu adegan film tersebut. Informasi berkembang dengan sangat cepat mempengaruhi peersepsi masyarakat secara luas.

\section{Komunikasi Lintas Budaya}

Komunikasi adalah proses dimana suatu ide dialihkan dari sumber kepada suatu penerima atau lebih, dengan maksud untuk mengubah tingkah laku mereka. Kebudayaan adalah keseluruhan yang kompleks, yang di dalamnya terkandung ilmu pengetahuan, kepercayaan, kesenian, moral, hukum, adat istiadat, kemampuan yang lain serta kebiasaan yang didapat oleh manusia sebagai anggota masyarakat.

Jika digabungkan dari kedua pengertian tentang Komunikasi dan kebudayaan (budaya) maka akan mendapatkan pengertian sebagai berikut : Komunikasi Lintas budaya adalah proses dimana dialihkan ide atau gagasan suatu budaya yang satu kepada budaya yang lainnya dan sebaliknya, dan hal ini bisa antar dua kebudayaan yang terkait ataupun lebih, tujuannya untuk saling mempengaruhi satu sama lainnya, baik itu untuk kebaikan sebuah kebudayaan maupun untuk menghancurkan suatu kebudayaan, atau bisa jadi sebagai tahap awal dari proses akulturasi atau penggabungan dua kebudayaan atau lebih yang menghasilkan kebudayaan yang baru. (Rahmad, 2014). 
Diterbitkan oleh Program Studi IImu Komunikasi

Universitas Ahmad Dahlan Yogyakarta

\section{Metode Penelitian}

\section{Pendekatan Penelitian}

Pendekatan yang digunakan dalam penelitian ini adalah pendekatan fenomenologi. Fenomenologi berusaha untuk mengungkap dan mempelajari serta memahami suatu fenomena beserta konteksnya yang khas dan unik yang dialami oleh individu hingga tataran "keyakinan" individu yang bersangkutan. Dengan demikian dalam mempelajari dan memahaminya, haruslah berdasarkan sudut pandang, paradigma dan keyakinan langsung dari individu yang bersangkutan sebagai subjek yang mengalami langsung.

Menurut Creswell (2009), terdapat beberapa prosedur dalam melakukan studi fenomenologi. Pertama, penulis harus memahami perspektif dan filosofi yang ada di belakang pendekatan yang digunakan, khususnya mengenai konsep studi "bagaimana individu mengalami suatu fenomena yang terjadi”. Konsep epoche merupakan inti ketika peneliti mulai menggali dan mengumpulkan ide-ide mereka mengenai fenomena dan mencoba memahami fenomena yang terjadi menurut sudut pandang subjek yang bersangkutan.

Konsep epoche adalah mengesampingkan atau menghilangkan semua prasangka (judgement) peneliti terhadap suatu fenomena. Artinya, sudut pandang yang digunakan benar-benar bukan merupakan sudut pandang penulis, melainkan murni sudut pandang subjek penelitian. Kedua, penulis membuat pertanyaan penelitian yang mengeksplorasi serta menggali arti dari pengalaman subjek dan meminta subjek untuk menjelaskan pengalamannya tersebut. Ketiga, penulis mencari, menggali, dan mengumpulkan data dari subjek yang terlibat secara langsung dengan fenomena yang terjadi. Keempat, setelah data terkumpul, penulis melakukan analisis data yang terdiri atas tahapan-tahapan analisis. Kelima, laporan penelitian fenomenologi diakhiri dengan diperolehnya pemahaman yang lebih esensial.

\section{Unit Analisi Data}

Penelitian ini menggunakan unit analisis data berupa masyarakat Jawa yang penulis ambil dari dua kasta, yaitu kasta atas dan kasta bawah. Kasta atas terdiri dari kaum bangsawan atau ningrat, sedangkan kasta bawah terdiri dari kaum biasa atau rakyat dengan masing-masing berjumlah tiga narasumber.

\section{Jenis data penelitian}

a. Data primer

Data primer merupakan data yang diperoleh secara langsung dari objek/subjek penelitian perorangan, kelompok, dan organisasi (Ruslan, 2003:29). Dalam penelitian ini data primer adalah data yang diperoleh dari wawancara dengan narasumber penelitian.

b. Data sekunder

Data sekunder merupakan data dalam bentuk sudah jadi (tersedia) melalui publikasi dan informasi yang dikeluarkan diberbagai organisasi termasuk majalah, jurnal dan literature lain yang relevan. (Ruslan, 2003:29) 
c. Metode Pengumpulan Data

Metode pengumpulan data dilakukan dengan beberapa cara yaitu:

1. Wawancara

Wawancara mendalam digunakan untuk mendapatkan pengalaman dan kesadaran narasumber tentang pesan dibalik lagu "Lingir Wengi". Wawancara adalah percakapan dengan maksud tertentu. (Moleong, 2001: 135). Dengan wawancara, data dikumpulkan melalui tanya jawab secara mendalam (indept interview) dan langsung kepada narasumber. Narasumber yaitu orang yang dimanfaatkan untuk memberikan informasi tentang situasi dan latar penelitian. (Moleong, 2001: 90).

2. Studi pustaka

Studi pustaka dilakukan untuk mendapatkan data sekunder yang relevan dengan penelitian untuk merefleksikan sejumlah hasil temuan penelitian.

\section{E. Pembahasan}

\section{Faktor yang mempengaruhi persepsi}

Faktor eksternal: Ukuran dan penempatan dari obyek atau stimulus. Faktor ini menyatakan bahwa semakin besarnya hubungan suatu obyek, maka semakin mudah untuk dipahami. Bentuk ini akan mempengaruhi persepsi individu dan dengan melihat bentuk ukuran suatu obyek individu akan mudah untuk perhatian pada gilirannya membentuk persepsi.

Penulis menggarisbawahi kalimat semakin besarnya hubungan suatu obyek, maka akan semakin mudah untuk dipahami. Kalimat ini mempunyai arti bahwa hubungan antara Sunan Kalijaga dengan masyarakat Jawa sangat erat. Sunan Kalijaga yang dianggap "guru" dalam menyebarkan syiar agama Islam dianggap dekat dengan masyarakat Jawa karena kharisma dan ilmu agama yang dimilikinya. Sehingga apapun yang dikerjakan oleh sang guru selalu dianut oleh pengikutnya, bahkan sampai saat ini.

Begitu banyak media dakwah yang dilakukan oleh Sunan Kalijaga dalam menyebarkan agama Islam, salah satunya dengan menciptakan lagu "Lingsir Wengi". Pada awalnya lagu ini memang dianggap sebagai dakwah agama Islam karena syair yang mengandung doa menolak bala.

Pernah dipakai untuk backsound salah satu film horor yang berjudul "Kuntilanak" membuat konsep berpikir masyarakat Jawa kelas bawah berubah. Yang sebelumnya tidak pernah tau apa itu "Lingsir Wengi" menjadi tau, dan awal mula pengetahuannya bernuansa negatif, karena dalam adegan film itu dipersepsikan bahwa lagu "Lingsir Wengi adalah lagu untuk memanggil roh halus.

Faktor internal: Fisiologis. Informasi masuk melalui alat indera, selanjutnya informasi yang diperoleh ini akan mempengaruhi dan melengkapi usaha untuk memberikan arti terhadap lingkungan sekitarnya. Kapasitas indera untuk mempersepsi pada tiap orang berbeda-beda sehingga interpretasi terhadap lingkungan juga dapat berbeda. 
Diterbitkan oleh Program Studi IImu Komunikasi

Universitas Ahmad Dahlan Yogyakarta

Masyarakat yang menonton film horor menjadi takut dengan lagu "Lingsir Wengi" karena ada pengaruh dari indera pendengaran dan penglihatan tentang apa yang dilihat pertama kali. Ini yang memunculkan pendapat atau sudut pandang yang terbalik dari sebuah informasi. Kemudian menyebarlah informasi yang "dikemas" dengan persepsi yang salah, sehingga orang yang menerima informasi secara tidak langsung akan mempercayainya.

\title{
2. Makna Lagu "Lingsir Wengi"
}

Durmo lingsir wengi merupakan arti lagu penolak mahluk halus, namun beberapa dari masyarakat salah mengartikan menjadi pengundang mahkluk halus. Lagu "Lingsir Wengi" diciptakan sebagai penolak bala godaan mahluk halus.

Mari kita perhatikan lirik lagu asli yang diciptakan oleh Sunan Kalijaga beserta artinya dibawah ini:

\author{
Lingsir Wengi \\ Lingsir wengi \\ Sepi durung biso nendro \\ Kagodho mring wewayang \\ Kang ngreridhu ati \\ Kawitane \\ Mung sembrono njur kulino \\ Ra ngiro yen bakal nuwuhke tresno \\ Nanging duh tibane aku dewe kang nemahi \\ Nandang bronto \\ Kadung loro \\ Sambat-sambat sopo \\ Rino wengi \\ Sing tak puji ojo lali \\ Janjine mugo biso tak ugemi
}

Arti dalam bahasa Indonesia:

\author{
Menjelang Tengah Malam \\ saat menjelang tengah malam \\ sepi tidak bisa tidur \\ tergoda bayanganmu \\ di dalam hatiku \\ permulaanya \\ hanya bercanda kemudian terjadi \\ tidak mengira akan jadi cinta \\ kalau sudah saatnya akan terjadi pada diriku \\ menderita sakit cinta(jatuh cinta) \\ aku harus mengeluh kepada siapa \\ siang dan malam \\ yang saya cinta jangan lupakan $k u$ \\ janjinya kuharap tak diingkari
}

Sedangkan syair yang ada pada film kuntilanak adalah: 


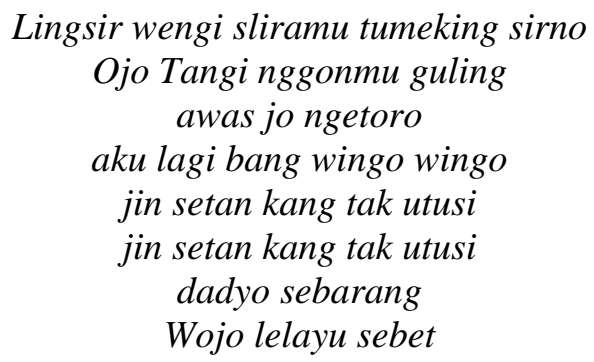

Bisa kita artikan dalam bahasa Indonesia:

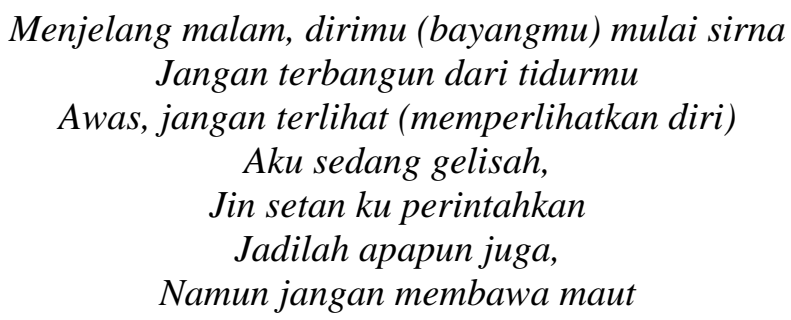

\section{Sebagai Syiar Agama Islam}

Sejarah mengatakan, tidak ada kata dalam syair lagu "Lingsir Wengi" yang mengarah kepada pemanggilan roh halus. Ini hanya persepsi masyarakat saja yang dibentuk karena melihat film kuntilanak. Terbukti, sebelum ada film kuntilanak, persepsi masyarakat Jawa tidak seperti sekarang ini. Banyak kasta bawah yang menterjemahkan lagu ini sebagai pemanggil roh karena terpengaruh film kuntilanak.

Penulis mewawancarai seorang Kyai yang berdomisili di Kota Gede Yogyakarta. Narasumber menjelaskan dengan detail mulai dari sejarah hingga persepsi masyarakat Jawa tentang lagu "Lingsir Wengi" ini. Menurut narasumber, lagu "Lingsir Wengi itu tidak ada, yang ada adalah "Kidung Rumekso ing wengi". Rumekso adalah lawan kata dari terpaksa, berarti iklas, sedangkan malam adalah malam, sehingga jika digabungkan menjadi iklas tengah malam. Penulis menterjemahkan hasil wawancara sebagai berikut. Menurut narasumber, cara pertama untuk menterjemahkan syair lagu sebagai dakwah agama Islam adalah dengan melihat syair aslinya.

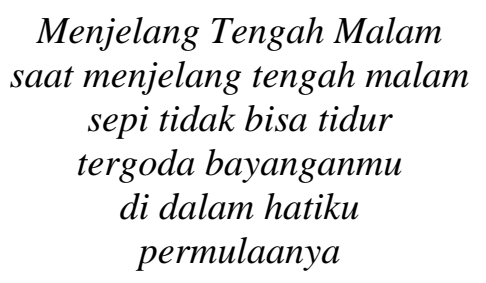

Arti kata menjelang tengah malam adalah manusia disarankan untuk siap-siap menyambut datangnya sepertiga malam, atau pada intinya disarankan untuk bersiap sholat tahajud. Kenapa memakai tengah malam dan bukan sepertiga malam. Pada jamannya wali songo, setiap wali sebelum melakukan sholat malam (tahajud) berdzikir terlebih dahulu, sehingga ini akan menenangkan hati ketika menghadap Allah SWT. Kata "tergoda bayangmu didalam hatiku pemulanya" adalah Sunan Kalijaga selalu mengingat 
Diterbitkan oleh Program Studi IImu Komunikasi

Universitas Ahmad Dahlan Yogyakarta

Allah dan bayang-bayang Allah selalu menghiasi wajahnya, hati pemulanya berarti sebuah hati manusia yang tidak tau apa-apa dan hanya Allah sumber ilmu untuk hidup di dunia, untuk itu Sunan Kalijaga menuliskannya dengan kata pemula atau awal atau bayi.

\author{
hanya bercanda kemudian terjadi \\ tidak mengira akan jadi cinta \\ kalau sudah saatnya akan terjadi pada diriku \\ menderita sakit cinta (jatuh cinta) \\ aku harus mengeluh kepada siapa \\ siang dan malam \\ yang saya cinta jangan lupakan $k u$ \\ janjinya kuharap tak diingkari
}

Dalam bait yang kedua ini diterjemahkan sebagai seseorang yang awalnya tidak bermaksud apa-apa atau hanya bercanda (bayi kegemarannya bercanda) dan tidak mengira akan menjadi "kekasih" yang dituju, yaitu Allah, menjadi orang yang paling dekat dengan Allah akan berdampak pada sakit cinta (atau ketergantungan), dan ketika itu tidak terjadi maka manusia akan bergantung kepada siapa? Hanya kepada Allah saja manusia itu kembali dan menyembah. Arti dari syair ini sama dengan ayat ke lima dalam

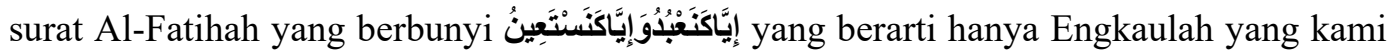
sembah, dan hanya kepada Engkaulah kami meminta pertolongan.

Sunan Kalijaga mengambil ayat ke lima (5) dari surat Al-Fatihah dengan maksud memberikan sebuah penekanan bahwa manusia wajib melaksanakan sholat lima waktu yang terdiri dari Subuh, Dhuhur, Ashar, Magrib dan Isya, itulah makna dari agama Islam (Ingin Selamat Laksanakan Ajaran Muhammad) karena Nabi Muhammad dalam perjalanan spektakulernya menerima perintah sholat lima waktu. Lalu diterjemahkan kedalam syair lagu yang difilsafatkan dari ayat ke lima surat Al-Fatihah.

Kata siang dan malamyang saya cinta jangan lupakan kujanjinya kuharap tak diingkarimaksudnya adalah setiap hari Sunan Kalijaga menyarankan agar manusia selalu ingat kepada Allah, dan berharap Allah tidak melupakannya di dunia. (Hasil wawancara 20 Oktober 2016 jam 15.25 WIB)

\title{
4. Sebagai Komunikasi Lintas Budaya
}

Berkenaan dengan pembahasan komunikasi antarbudaya, Cahyono (2012) mengklasifikasikan pengertian komunikasi lintas budaya berkaitan dengan tata bahasa kedalam beberapa difinisi, diantaranya.

a. Komunikasi dan bahasa

Sistem komunikasi, verbal dan non-verbal, satu unsur yang membedakan satu kelompok dengan kelompok lainnya. Ada banyak ragam bahasa utama dan tiap tiap-nya terdapat dialek, logat, jargon dan lainnya. Belum lagi gerak gerik bahasa tubuh yang mungkin universal namun beda makna secara lokal atau kultural.

b. Waktu dan kesadaran akan waktu

Hal ini menyangkut pandangan orang akan waktu. Sebagian orang tepat waktudan sebagian lain berpandangan merelatifkan waktu. Ada orang yang 
tidakmemperdulikan jam atau menit tapi hanya menandai waktunya dengan saat matahari terbit atau saat matahari terbenam saja.

c. Nilai dan Norma

Berdasarkan sistem nilai yang dianutnya, suatu budaya menentukan normanormaperilaku bagi masyarakat yang bersangkutan. Aturan ini bisa berkenaan denganberbagai hal, mulai dari etika kerja atau kesenangan hingga kepatuhan mutlak atau kebolehan bagi anak-anak.

d. Rasa Diri dan Ruang

Kenyamanan yang dimiliki seseorang atas dirinya bisa diekspresikan secara berbedaoleh masing-masing budaya. Beberapa budaya sangat terstruktur dan formal, sementara budaya lainnya lebih lentur dan informal. Beberapa budaya sangattertutup dan menentukan tempat seseorang secara persis, sementara budaya-budaya lain lebih terbuka dan berubah.

e. Proses mental dan belajar

Beberapa budaya menekankan aspek perkembangan otak ketimbang aspek lainnyasehingga orang dapat mengamati perbedaan-perbedaan yang mencolok dalam caraorang-orang berpikir dan belajar.

\section{Persepsi Masyarakat Jawa Terhadap Lagu "Lingsir Wengi"}

Dari pembahasan diatas, merujuk pada satu hipotesis bahwa persepsi dipengaruhi oleh beberapa hal yang terdapat dalam faktor internal dan eksternal, kemudian komunikasi budaya juga mengandung berbagai macam unsur. Lalu kemudian jika itu semua disatukan lalu dikaitkan dengan persepsi masyarakat Jawa, maka akan mengarah kepada satu persepsi bahwa lagu "Lingisr Wengi yang sebenarnya bernama Ruwokso Wengi adalah negatif, ini berdasarkan hasil wawancara dengan enam narasumber yang terbagi menjadi dua kelas atau dua kasta.

a. Kasta atas

Yang dimaksud dengan kasta atas disini ialah kaum bangsawan, atau kerabat kerajaan, atau kaum ningrat (Kraton Yogyakarta). Dari tiga narasumber yang penulis wawancarai mengatakan bahwa persepsi mereka tentang keberadaan lagu "Lingsir Wengi mengarah kepada hal-hal yang bersifat adikodrati atau supranatural. Narasumber menjelaskan bagaimana kisah dan epistemologi dari lagu lingsir wengi. Dari tiga narasumber yang penulis wawancarai, dua diantaranya berpendapat lain tentang lagu lingsir wengi, pendapat tersebut mengarah kepada satu esensi tentang makna dibalik syair lingsir wengi. Dua narasumber mengatakan dan menjelaskan bahwa lagu tersebut merupakan sebuah pesan untuk mendekatkan diri kepada sang maha kuasa yaitu Allah SWT. Ini mengarah ke kecenderungan pesan positif dibalik syair lagu ersebut tentang dakwah atau syiar agama Islam.

b. Kasta bawah

Yang dimaksud dengan kasta bawah disini ialah rakyat atau warga, atau masyarakat secara umum yang tinggal di desa atau kampung-kampung. Penulis mewawancarai tiga orang dari kalangan kasta bawah, ketiga narasumber mengatakan bahwa lagu lingsir wengi adalah lagu pemanggil roh. Alasannya 
Diterbitkan oleh Program Studi IImu Komunikasi

Universitas Ahmad Dahlan Yogyakarta

sederhana karena nada yang dinyanyikan pelan, alasan kedua ialah informasi yang tersebar dan menyebar tentang lagu ini ialah negatif. Narasumber hanya mendengar saja lalu mempersepsikan sesuai dengan apa yang dipikirkan, sehingga informasi yang diterima mempengaruhi kognitif manusia. Penulis bertanya apa yang menyebabkan narasumber mengatakan bahwa lagu lingsir wengi mempunyai kekuatan magis? Narasumber tidak bisa menjawab dengan detail pertanyaan penulis. Dari jawaban narasumber ini, penulis dapat menyimpulkan bahwa persepsi yang dibangun masyarakat Jawa dipengaruhi oleh informasi yang tidak utuh dan hanya bersifat apriori saja tanpa adanya pembuktian empirisme yang mendalam.

\section{F. Kesimpulan}

Dari pembahasan diatas, dapat ditarik sebuah hipotesis bahwa persepsi akan mempengaruhi pandangan manusia, jenis pesan yang disampaikan hanya ditelaah secara setengah-setengah atau tidak utuh, sehingga memunculkan satu permaknaan yang berbeda antara persepsi satu dengan persepsi yang lainnya. Sebuah kajian yang menarik untuk disimpulkan bahwa sebenarnya lagu "Lingisr Wengi atau Ruwokso Wengi adalah satu dimensi spiritual yang mengetengahkan model dakwah berbasis budaya yang dikomunikasikan secara parsial oleh sang penciptanya yaitu Sunan Kalijaga.

Dimensi yang dimiliki manusia menuntun hasil penelitian ini kepada satu jawaban sementara yaitu lagu lingsir wengi merupakan sarana dakwah yang berbasis komunikasi budaya. Salah satu dimensi yang digunakan oleh Sunan Kalojaga dalam mendakwahkan lagu ini ialah dengan dimensi spiritual yaitu memberikan pengertian dan sifat persuasif kepada masyarakat untuk menelaah makna Tuhan secara mendalam dan mendalami ajaran Islam dengan baik dan benar.

\section{Daftar Pustaka}

Abdullah, P. D. (2015). Kontruksi dan Reproduksi Kebudayaan. Yogyakarta: Pustaka Pelajar.

Abimanyu, S. (2014). Babad Tanah Jawi. Jakarta: Laksana.

Cahyono, B. R. (2012). Komunikasi Lintas Budaya . Yogyakarta: Bumi Aksara.

Crain, W. (2007). Teori Perkembangan Konsep dan Aplikasi . Yogyakarta: Pustaka Pelajar.

Hoed, B. H. (2015). Semiotik Dinamika Sosial Budaya. Yogyakarta: Pustaka Pelajar.

Josep, M. L. (2004). Metode Penelitian Kualitatif. Bandung: PT Rosda Karya.

Radtya, A. (2003). Persepsi Komunikasi . Yogyakarta: Pustaka pelajar.

Rahmat, J. (1994). Psikologi Komunikasi . Bandung: Rosdakarya.

Rahyono, F. (2015). Kearifan Budaya Dalam Kata. Yogyakarta: Wedatama Widya Sastra.

Soebachman, A. (2015). Hikayat Bumi Jawa. Yogyakarta: Syura Media Utama. 
Wirosardjono, S. (2007). Simbol Budaya dan Teladan Kepemimpinan. Jakarta: Penerbit Buku Kompas. 